\title{
Genotype by Environment Interaction Unravels Influence on Secondary Metabolite Quality in Cassava Infested by Bemisia tabaci
}

\author{
N. Mwila ${ }^{1}$, E. Nuwamanya ${ }^{2}$, T. L. Odong ${ }^{1}$, A. Badji ${ }^{1}$, S. Agbahoungba ${ }^{1}$, P. A. Ibanda ${ }^{1}$, M. Mwala ${ }^{3}$, P. Sohati ${ }^{3}$, \\ S. Kyamanywa ${ }^{1} \&$ P. R. Rubaihayo ${ }^{1}$ \\ ${ }^{1}$ Department of Agricultural Production, College of Agricultural and Environmental Sciences, Makerere \\ University, Kampala, Uganda \\ ${ }^{2}$ National Crops Resources Research Institute, Namulonge, Kampala, Uganda \\ ${ }^{3}$ Department of Plant Science, School of Agricultural Sciences, University of Zambia, Lusaka, Zambia \\ Correspondence: N. Mwila, Department of Agricultural Production, College of Agricultural and Environmental \\ Sciences, Makerere University, P.O. Box 7062, Kampala, Uganda. E-mail: mwilanatasha@yahoo.co.uk
}

Received: March 15, 2018

doi:10.5539/jas.v10n8p192

\author{
Accepted: May 10, $2018 \quad$ Online Published: July 15, 2018 \\ URL: https://doi.org/10.5539/jas.v10n8p192
}

\begin{abstract}
Cassava resistance to Bemisia tabaci is a result of many plant processes which involve plant biochemical constituents, shown to be affected by genotype and environment. The objective of this study was to assess the effect of genotype $\times$ environment interactions on concentrations of tannin, flavonoid, total phenolic content, antioxidative capacity and B. tabaci resistance. Fifteen cassava genotypes were evaluated monthly for tannin, flavonoid, total phenolic content and antioxidative capacity in three locations over two seasons with varying temperatures and rainfall. In addition, data were collected on B. tabaci population density and damage. The data collected was subjected to analysis of variance and additive main effects and multiplicative interactions (AMMI) analyses. Flavonoid, total phenolic content and antioxidative capacity varied significantly $(\mathrm{P}<0.001)$ across seasons with higher concentrations in season one than season two, attributed to different temperature and rainfall readings. Total phenolic content was significantly $(\mathrm{P}<0.001)$ associated to antioxidative capacity $(\mathrm{r}=0.83)$ and temperature $(\mathrm{r}=0.91)$. Leaf damage due to adult whitefly and nymphs was significantly $(\mathrm{P}<0.001)$ negatively correlated $(\mathrm{r}=-0.67)$ to antioxidative capacity. Genotypes UG 120257, UG 120291 and UG 120124 were shown to have high antioxidative capacity and more stable performance across environments. Temperature and $B$. tabaci feeding influenced concentrations of the phenolic content and antioxidative activity, as a result affected cassava resistance.
\end{abstract}

Keywords: AMMI, antioxidative capacity, flavonoid, leaf damage, moisture, phenolics, plant-insect interactions, tannin, temperature

\section{Introduction}

Cassava (Manihot esculenta Crantz), one of the most important food root crops in Uganda is cultivated over an area of 852,000 ha but has relatively low average productivity (FAO, 2017). Insect pests and environmental factors are major contributors to low cassava production (Nweke, 2009). Insect species for instance Bemisia tabaci, cause direct damage (Bellotti \& Arias, 2001), act as vectors of African cassava mosaic disease (ACMD) (CIAT, 2005) and have been reported to adversely affect cassava yields by $79 \%$ (CIAT, 2011). The combinations of insects and environmental factors in natural environments, severely affect plants such as cassava (Kloth, Thoen, Bouwmeester, Jongsma, \& Dicke, 2012). Bemisia tabaci infestation (War et al., 2012), temperature and moisture stress (Pandey, Irulappan, Bagavathiannan, \& Senthil-Kumar, 2017) result in biochemical and physiological plant defensive mechanisms (Kant et al., 2015). The processes lead to alteration in metabolite pool of affected plants (Ncube, Finnie, \& Van Staden, 2012) sometimes causing a negative impact on plant insect interactions (Jamieson et al., 2017), lower plant fitness (Huber et al., 2016) and affect total cassava starch yields of up to $100 \%$ (Nuwamanya et al., 2014). Some studies have reported the complexity of plant responses to combinations of attacks making it impossible to directly infer from pairwise plant-insect interactions (Barah \& Bones, 2017). 
The effects of rapidly accelerating environmental changes on local and global scales (Ballhorn et al., 2011) affect plant insect interactions (Jamieson et al., 2017). The simultaneous occurrence of pests and other environmental stresses can either impose a negative (susceptibility) or positive (tolerance) effect on plants depending on the stress, pathogen (Rejeb, Pastor, \& Mauch-Mani, 2014), crop and duration of each stress affecting the plant (Ramegowda \& Senthil-Kumar, 2015). However, plants have co-evolved with the environment and developed an array of resistance mechanisms to prevent insect attacks (Kempema, Cui, Holzer, \& Walling, 2007) and maintain growth in stressful climatic conditions (Hasanuzzaman, Nahar, \& Fujita, 2009).

Biotic stresses (including Bemisia tabaci feeding) (War et al., 2012) and abiotic factors specifically varying temperature and moisture trigger multiple biochemical products; protein (Kimmins et al., 2005), phenolics (Fürstenberg-hägg, Zagrobelny, \& Bak, 2013), antioxidants (Fürstenberg-hägg et al., 2013), jasmonic acid/ethylene and peroxidase (Nuwamanya et al., 2014; Pandey et al., 2017), based on various pathways. This is due to plants incorporating a variety of environmental signals into their developmental pathways that provide for their wide range of adaptive capacities over time (Fürstenberg-hägg et al., 2013). However, the changes in metabolite concentration do not always occur in predictable ways (Moore, Andrew, Külheim, \& Foley, 2014). Little is known about the phenotypic plasticity of these biochemicals in nature (Ballhorn et al., 2011) and the effect on plant insect interactions (Bohorquez, Tohme, Parsa, \& López-lavalle, 2001), suggesting that a consideration of environmental factors as well as plant insect herbivory over a substantial period of time is vital in understanding plant insect resistance.

Phenolics, in particular, tannins and flavonoids are among many secondary metabolites reported to be initiated through leaf injury by $B$. tabaci eventually affecting resistance to B. tabaci (Fürstenberg-hägg et al., 2013; Sulistyo \& Inayati, 2016). Changes in phenolic concentrations (Zobayed, Afreen, Goto, \& Kozai, 2006; Nuwamanya et al., 2014), modify lipid packing order and reduce fluidity of plant membranes (Sharma, Jha, Dubey, \& Pessarakli, 2012). The changes in phenolic content result in increased antioxidative power (Fürstenberg-hägg et al., 2013) via protein denaturation (Ncube et al., 2012) and lead to decreased nutrient availability (Stevens, Waller, \& Lindroth, 2007). Temperature and moisture stress also not only affect cell water potential $\left(\mathrm{V}_{\mathrm{m}}\right)$ as a result of xylem pressure (Ncube et al., 2012) but alter antioxidative properties of plants (Lemoine, Burkepile, \& Parker, 2014; Ncube et al., 2012). This occurs through chelating transition metal ions, direct scavenging of molecular species of active oxygen, trapping the lipid alkoxyl radical (Sharma et al., 2012) and lipid peroxidation (Apak, Özyürek, Güçlü, \& Çapanołlu, 2016). The changes that occur in the amounts of phenolic, tannin, flavonoid and antioxidative capacity reduce plant palatability and defense to insect pests (Stevens et al., 2007). In cassava, the quantitative extent to which phenolic content and antioxidative capacity responds to changing abiotic conditions, its effect on natural plant-insect interactions and resistance, is however, still poorly understood (Tylianakis, Didham, Bascompte, \& Wardle, 2008). Information on the effect and adaptability that simultaneous $B$. tabaci feeding, temperature and rainfall changes have on phenolic content and antioxidative capacity could bridge gaps in knowledge of cassava resistance to B. tabaci.

The ultimate goal in breeding for cassava resistance to pests is the possibility of developing varieties that have relative resistance to $B$. tabaci adapted to a wide range of environments (Alicai et al., 2016), forming a basis of an integrated approach to B. tabaci control and ACMD control. The objective of the study focused on assessing genotype $\times$ environment interaction (GEI) and Bemisia tabaci effect on tannin, flavonoid, total phenolic concentration and antioxidative capacity.

\section{Material and Methods}

\subsection{Plant Materials and Study Sites}

Fifteen cassava genotypes previously screened for resistance to whitefly, of which nine were resistant and six susceptible, were obtained from National Crop Resources Research Institute (NaCRRI) under the cassava breeding program in Uganda. UG 120133, UG 120191, UG 120251, UG 120293, CS1-144, UG 120257, UG 120124, UG 120291 and UG 120160 were resistant. UG 130068, UG 130075, UG 130038 and UG 120001 were susceptible. NAM 130 and NASE 13 were the resistant and susceptible controls respectively. The genotypes were assessed for two consecutive seasons, 2016A (January-July-Season 1) and 2016B (July-January-Season 2). The study was conducted at three locations (Namulonge, Kamuli and Kasese) (Table 1). The locations represented whitefly hot spot areas (Adriko et al., 2011) and belong to different agro ecological zones (AEZ) (Caffrey et al., 2013). Namulonge is located in Central Uganda $\left(32^{\circ} 37^{\prime} \mathrm{N} ; 0^{\circ} 32^{\prime} \mathrm{E}\right)$, receives rainfall $\sim 1200$ $\mathrm{mm}$ /year at altitude $1150 \mathrm{~m}$ asl. (Tukamuhabwa, Oloka, Sengooba, \& Kabayi, 2012) and belongs to lake victoria crescent and mbale farmlands AEZ. Kamuli is located in Eastern Uganda $\left(33^{\circ} 06^{\prime} \mathrm{N} ; 0^{\circ} 55^{\prime} \mathrm{E}\right)$, receives rainfall of $1130 \mathrm{~mm}$ per year at an altitude $1350 \mathrm{~m}$ asl. (Paparu et al., 2017) and belongs to southern and eastern lake kyoga 
basin AEZ. Kasese is located in Western Uganda $\left(30^{\circ} 05^{\prime} \mathrm{N} ; 0^{\circ} 11^{\prime} \mathrm{E}\right)$, receives rainfall of $\sim 1600 \mathrm{~mm} / \mathrm{year}$ and at altitude $920 \mathrm{~m}$ asl. (Kayondo et al., 2017) and belongs to western medium-high farmlands AEZ.

Table 1. Mean temperature and rainfall per season in three locations

\begin{tabular}{lllll}
\hline Location & Season & Temperature (Max) ${ }^{\circ} \mathbf{C}$ & Temperature (Min) ${ }^{\circ} \mathbf{C}$ & Rainfall $(\mathbf{m m})$ \\
\hline Namulonge & 1 & 29.68 & 16.26 & 93.80 \\
& 2 & 27.82 & 15.93 & 37.00 \\
Kamuli & 1 & 33.03 & 15.95 & 64.50 \\
& 2 & 28.50 & 15.74 & 26.80 \\
Kasese & 1 & 31.89 & 18.98 & 56.10 \\
& 2 & 29.23 & 17.41 & 72.40 \\
\hdashline-1.58 & 0.84 & 37.52 \\
Location LSD $(0.05)$ & & 1.95 & 1.02 & 45.95 \\
\hline
\end{tabular}

Note. Max: maximum; Min: minimum; LSD: least significant difference at $5 \%$; ${ }^{\circ} \mathrm{C}$ : Degrees celcius; mm: millimeters.

\subsection{Experimental Design}

The genotypes were planted in a randomized complete block design (RCBD) with three replications in three locations for two seasons. The first planting was done using 1-2 cuttings per hole, in December, 2015 and the second in June, 2016. Each plot measured a total of $70 \mathrm{~m}^{2}$, consisting of 15 rows of $5 \mathrm{~m}$ long and $1 \mathrm{~m}$ apart with intra row spacing of $1 \mathrm{~m}$ with $2 \mathrm{~m}$ between replications. Regular weeding of the fields till maturity were done with a hand hoe.

\subsection{Data Collection}

All the plant data were collected from three tagged plants randomly selected per row per plot. The following data was collected on the top five fully expanded apical leaves; nymph count, whitefly count (Bellotti, 2002) and a leaf damage score (Bellotti \& Arias, 2001) recorded monthly for six months in each experiment.

Total phenolic content (TPC), tannins, flavonoids and antioxidative capacity were analyzed on 2-7 leaves and petiole sap of the same leaves per plant per genotype sampled monthly for the two seasons. The leaves were weighed using an electronic scale and placed in a ziplock bag. Petiole sap was collected between 07:30 am-12:00 pm (HoRTUS Technical, 2017) directly into a $1.5 \mathrm{ml}$ vial which had $0.5 \mathrm{ml}$ of $0.1 \mathrm{M}$ phosphate buffer to prevent the coagulation of the sap due to the development of P-protein which enhances callose development (van Bel, 2006). The leaf and sap samples were immediately placed in ice boxes at $4{ }^{\circ} \mathrm{C}$ and later placed in a refridgerator at $-20{ }^{\circ} \mathrm{C}$ (HoRTUS Technical, 2017).

Temperature data measured from a U-shaped thermometer and rainfall amounts based on rain gauge readings, were collected monthly from meteorological stations in the three respective locations (Namulonge, Kamuli and Kasese). The means of temperature (maximum and minimum) and rainfall across the locations are presented in Table 1.

\subsubsection{Total Phenolic Content Determination}

A $50 \mathrm{mg}$ leaf sample was homogenized with distilled water to obtain aqueous extract. $200 \mu \mathrm{L}$ of extract $(1 \mathrm{mg} / \mathrm{ml})$ was collected in a test tube and made up to $3 \mathrm{ml}$ with distilled water. The mixture was sonicated for 5 minutes using an orbital shaker to obtain a homogenized solution. Centrifugation was done at $600 \mathrm{rpm}$ for 10 minutes. To $200 \mathrm{ml}$ of the supernatant taken in a test tube, $0.5 \mathrm{ml}$ Folin-Ciocalteu reagent were added. Then, after 3 minutes incubation at $24{ }^{\circ} \mathrm{C}, 2 \mathrm{ml}$ of $20 \%(\mathrm{w} / \mathrm{v})$ sodium carbonate solution was added and the test tube was covered with aluminum foil and incubated in a hot water bath at $40{ }^{\circ} \mathrm{C}$ for 60 minutes. A blank was prepared using the same procedure but replacing the plant extract with an equal volume of water. The absorbance of the sample was determined using a UV visible spectrophotometer (Biowaveii+, Cambridge, England) at $650 \mathrm{~nm}$ (Sharma et al., 2012). The standard curve of gallic acid was obtained using the same procedure (Maksimović \& Živanović, 2012). Total phenolic content was expressed as g of gallic acid equivalents (GAE) per ml, which was calculated using the formula, $y=5.3243 x-0.0183$, where, $y$ was the absorbance at $650 \mathrm{~nm}$ and $x$, the amount of gallic acid equivalent $(\mathrm{g} / \mathrm{ml})$. 


\subsubsection{Total Tannin Determination}

A $100 \mathrm{mg}$ leaf sample was placed into a $2 \mathrm{ml}$ eppendorf tube, where $0.5 \mathrm{mls}$ of $5 \%$ ascorbic acetone solution was added to dissolve leaf precipitate and placed on an orbital shaker for 20 minutes. To remove pigments, $0.5 \mathrm{mls}$ of petroleum ether containing $1 \%$ acetic acid was added and left on the bench until it all evaporated then $0.3 \mathrm{mls}$ of distilled water was added and centrifuged for 10 minutes at 1,000 rpm followed by adding $2.4 \mathrm{ml}$ of $5 \%$ hydrochloric acid (HCL)-butanol solution.

Each content in the tube was run through $240 \mathrm{~mm}$ filter paper and $0.5 \mathrm{ml}$ of the filtrate was made up to $1 \mathrm{ml}$ with distilled water in a conical flask. $0.5 \mathrm{ml}$ of folin ciocalteau reagent was added and mixed with $2.5 \mathrm{ml}$ of $20 \%$ sodium carbonate solution and mixed. $0.1 \mathrm{mls}$ of the mixture was then incubated at $80{ }^{\circ} \mathrm{C}$ for 1 hour and 20 minutes and the samples were cooled to $24{ }^{\circ} \mathrm{C}$ and spectrophotometric readings were taken at $550 \mathrm{~nm}$ (Harborne, 1998). A similar procedure was followed for the sap samples. A standard graph was constructed using tannic acid as a standard (Singh, Srivastava, \& Sahu, 2004), where, $\mathrm{Y}=10275 x+0.0605 ; \mathrm{R}^{2}=0.977$. The total tannin content was expressed as $\mathrm{g} / \mathrm{ml}$ (Anbuselvi \& Balamurugan, 2014).

\subsubsection{Total Flavonoid Content Determination}

A leaf sample $(50 \mathrm{mg})$ was homogenised with $2 \mathrm{ml}$ of $0.1 \mathrm{M}$ ice cold phosphate buffer at a $\mathrm{pH}=7.5$. Fifty microliter of the leaf extract was made up to $1 \mathrm{ml}$ with methanol and $4 \mathrm{ml}$ of distilled $\mathrm{H}_{2} \mathrm{O}$; followed by $0.3 \mathrm{ml}$ of $10 \%(\mathrm{w} / \mathrm{v})$ aluminium chloride $\left(\mathrm{AlCl}_{3}\right)$ solution after 5 minutes of incubation at $40{ }^{\circ} \mathrm{C}$, and then the mixture allowed to stand for 6 minutes (Zhang, Ye, Lin, Zhou, \& Zeng, 2009). Thereafter, $2 \mathrm{ml}$ of $1 \mathrm{M} \mathrm{NaOH}$ solution was added and brought to a final volume of mixture of $10 \mathrm{ml}$ with double distilled water. The mixture was allowed to stand for 15 minutes at $24{ }^{\circ} \mathrm{C}$ and absorbance measured at $510 \mathrm{~nm}$, using UV-visible spectrophotometer. A calibration curve of quercetin was obtained for concentrations ranging from 0.002 to $0.0014 \mathrm{~g} / \mathrm{ml}$ and the total flavonoid content of each extract was expressed as $\mathrm{g}$ of quercetin equivalents $(\mathrm{QE})$ per $\mathrm{ml}$. The curve was calculated using the formula, $y=293.64 x+0.0746$, where, $y$ is the absorbance at $510 \mathrm{~nm}$ and $x$, the amount of quercetin equivalent $(\mathrm{g} / \mathrm{ml})$ (Kumar \& Jain, 2015).

\subsubsection{Antioxidative Capacity}

Antioxidative capacity was determined using Ferric reducing antioxidant potential (FRAP) with modifications (Ahmed, Khan, \& Saeed, 2015). Plant material was extracted using 50\% aqueous methanol and then centrifuged (PrismaR, Edison, New Jersey, USA) at $1000 \mathrm{rpm}$ for 20 minutes to separate residues from supernatant. $0.1 \mathrm{ml}$ of the supernatant was added to a test tube, followed by $2.5 \mathrm{ml}$ of $80 \%$ phosphate buffered saline (PBS). Thereafter, $2.5 \mathrm{ml}$ of $1 \%$ potassium ferricyanide was added and the solution incubated for 20 minutes at $50{ }^{\circ} \mathrm{C}$. $2.5 \mathrm{ml}$ of $80 \%$ phosphoric acid was then added to the solution. The sample was centrifuged at 10,000 rpm for 10 minutes and $5 \mathrm{ml}$ of supernatant was transferred into a fresh tube and $5 \mathrm{ml}$ of distilled water was added, followed by $1 \mathrm{ml}$ of $0.1 \%$ ferric chloride. The sample was mixed well and absorbance read at $700 \mathrm{~nm}$ (Apak et al., 2016). In this assay, the presence of reducers (i.e., antioxidants) causes the reduction of the $\mathrm{Fe}^{3+} /$ ferricyanide complex to the ferrous form. The formation of blue-colored ferrous tripyridyltriazine complex $\left(\mathrm{Fe}^{2+}-\mathrm{TPTZ}\right)$ was measured at pH 3.6 spectrophotometrically (Apak et al., 2016).

Ascorbic acid was used as a standard with a stock solution of $5000 \mathrm{mg} / \mathrm{L}$ prepared in distilled water, from which dilutions were made ranging from $25 \mathrm{mg} / \mathrm{L}$ to $500 \mathrm{mg} / \mathrm{L}$. A blank was run using the same procedure but contained an equal volume of methanol in place of the plant sample. The antioxidative capacity was recorded as $\mathrm{g}$ of ascorbic acid equivalents (AAE) per ml (Kumar \& Jain, 2015).

\subsection{Statistical Analysis}

Analysis of variance for each season and each location was conducted using the linear model in Genstat 12.0. The linear Equation used was (Ntawuruhunga \& Dixon, 2010),

$$
Y_{i j k}=\mu+G_{i}+E_{j}+G E_{i j}+E_{i j k}
$$

Where, $Y$ was the response in terms of whitefly count, nymph count, damage, sooty mold, tannin flavonoid, total phenolic content and antioxidative capacity of the $j^{\text {th }}$ replication of genotype " $i$ " in environment " $k$ "; $\mu=$ overall mean of the responses; $G_{i}=$ genotype effect; $E_{j}=$ environment effect; $G E_{i j}=$ interaction effect; $E_{i j k}=$ experimental error.

A combined analysis of variance was done on the genotypes' nymph, whitefly count, leaf damage, sooty mold, tannin, flavonoid, total phenolic content and antioxidant activity across three locations and two seasons using linear mixed model (Restricted Maximum Likelihood-REML) procedure in GenStat 12.0 software (Kerchev, 
Fenton, Foyer, \& Hancock, 2012). A model described by Hongyu, García-Peña, Araújo, and Santos Dias (2014), was used as follows (Hongyu et al., 2014),

$$
\gamma_{i j k l}=\mu+\rho_{i}+l_{j}+S_{k}+r_{l}+b_{m(l)}+\rho l_{j i}+\rho s_{k i}+l s_{k j}+\rho l s_{i j k}+\varepsilon_{i j k l m}
$$

To test the significance of variation due to genotypes, locations, seasons, replications, blocks genotype $\times$ location, genotype $\times$ season, location $\times$ season and genotype $\times$ location $\times$ season interactions, a mixed model, with genotypes and locations as fixed effects and seasons and experimental error as random effect was assumed (Ntawuruhunga \& Dixon, 2010).

Nymph, whitefly count and damage means were separated using Fisher's Least Significant Difference (LSD) test at $5 \%$ probability level. Correlation and regression analyses was performed and the relationships among whitefly count, nymph count, leaf damage, sooty mold and genotypes as well as environments were assessed. The interrelations of changes in metabolite levels of tannins, flavonoid and antioxidant activity at varying environmental (temperature and rainfall) conditions and leaf damage were evaluated.

A combination of each location $(\mathrm{L}=3)$ and a season $(\mathrm{S}=2)$ constituted a single environment, however, the months with varying temperature and rainfall conditions and were considered as 6 different environments for AMMI analyses giving a total of 18 test environments.

The AMMI model combined two methods: analysis of variance and singular value decomposition in a unique model, additive components for the main effects of genotypes $\left(g_{i}\right)$, environments $\left(e_{j}\right)$ and multiplicative components for the interaction effect ( $g e)_{i j}$ (Adjebeng-Danquah, Manu-aduening, Gracen, Asante, \& Offei, 2017) The model equation used for the $i$-th genotype in the $j$-th environment in $r$ blocks (replications) was (Adjebeng-Danquah et al., 2017),

$$
Y_{i j r}=\mu+g_{i}+e_{j}+b_{r}\left(e_{j}\right)+\sum_{k=1}^{n} \lambda k \cdot \alpha_{i k} \gamma_{j k}+\rho_{i j}+\varepsilon_{i j}
$$

With components as described by Hongyu et al. (2014), where $Y$ is the phenotypic trait (e.g. leaf damage) of genotype. AMMI stability value (ASV) (Purchase, Hatting, \& van Deventer, 2000) was used to quantify and rank genotypes according to antioxidative capacity stability as the AMMI model does not make provision for a quantitative stability measure. The ASV was calculated as follows (Purchase et al., 2000),

$$
\text { AMMI stability value }=\text { AMMI stability value }=\sqrt{\left.\frac{\text { IPCA } 1 \text { sum of squares }}{\text { IPCA } 2 \text { sum of squares }} \text { (IPCA } 1\right)^{2}+(\text { IPCA 2) }}
$$

\section{Results}

\subsection{Cassava Leaf Responses to Bemisia tabaci by Location, Season and Genotype}

The results of the analyses of variance for all the traits tested are presented in Table 2. The locations and seasons significantly $(\mathrm{P}<0.001)$ differed for all the traits recorded and $(\mathrm{P}<0.01)$ for flavonoid and antioxidative capacity across seasons. Genotypes significantly $(\mathrm{P}<0.001)$ differed for all traits. The varying conditions across months significantly $(\mathrm{P}<0.001)$ influenced total phenolic concentration and antioxidative capacity, $(\mathrm{P}<0.01)$ for leaf damage and flavonoid concentrations and $(\mathrm{P}<0.05)$ leaf tannin concentrations.

Location and genotype interactions were significantly $(\mathrm{P}<0.001)$ different for nymph count, whitefly count, flavonoid, total phenolic content, antioxidative capacity and $(\mathrm{P}<0.01)$ for leaf damage and tannin. Season and genotype interactions had significant $(\mathrm{P}<0.001)$ differences for nymph count, whitefly count, sooty mold, flavonoid, total phenolic content and antioxidative capacity, $(\mathrm{P}<0.01)$ for leaf damage and $(\mathrm{P}<0.05)$ for tannin. There were significant $\mathrm{P}<0.001$ interaction effects among genotypes, locations and seasons on whitefly count, flavonoid, total phenolic concentrations and antioxidative capacity, $(\mathrm{P}<0.01)$ for nymph count and $\mathrm{P}<0.05$ for leaf damage and tannin concentrations. Genotypes, locations and months interactions showed significant $\mathrm{P}<$ 0.001 differences for flavonoid, total phenolic and antioxidative capacity and $(\mathrm{P}<0.01)$ for cassava leaf damage and tannin concentration. 
Table 2. Mean squares for different traits of cassava genotypes across three locations for two seasons

\begin{tabular}{|c|c|c|c|c|c|c|c|c|c|}
\hline $\begin{array}{l}\text { Sources of } \\
\text { variation }\end{array}$ & df & $\begin{array}{l}\text { Nymph } \\
\text { Count }\end{array}$ & $\begin{array}{l}\text { Whitefly } \\
\text { Count }\end{array}$ & $\begin{array}{l}\text { Leaf } \\
\text { Damage }\end{array}$ & $\begin{array}{l}\text { Sooty } \\
\text { Mold }\end{array}$ & $\begin{array}{l}\text { Tannin } \\
(\mathrm{g} / \mathrm{ml})\end{array}$ & $\begin{array}{l}\text { Flavonoid } \\
(\mathrm{g} / \mathrm{ml})\end{array}$ & $\begin{array}{l}\text { Total phenolic } \\
\text { content }(\mathrm{g} / \mathrm{ml})\end{array}$ & $\begin{array}{l}\text { Antioxidative } \\
\text { capacity }(\mathrm{g} / \mathrm{ml})\end{array}$ \\
\hline Location & 2 & $103834 * * *$ & $24831 * * *$ & $12.51 * * *$ & $2.26^{* * *}$ & $7.78 * * *$ & $3.33 * * *$ & $0.26 * * *$ & $4.67 * * *$ \\
\hline Season & 1 & $128889 * * *$ & $99202 * * *$ & $88.14 * * *$ & $22.09^{* * *}$ & $3.34 * * *$ & $0.21 * *$ & $1.09 * * *$ & $0.20 * *$ \\
\hline Location.Season & 2 & $77570 * * *$ & $57822 * * *$ & $38.64 * * *$ & $6.20 * * *$ & $1.93 * * *$ & $0.03 * * *$ & $0.96 * * *$ & $0.04 * *$ \\
\hline Genotype & 14 & $19806 * * *$ & $21012 * * *$ & $25.29 * * *$ & $4.41 * * *$ & $3.36^{* * *}$ & $11.78 * * *$ & $15.55 * * *$ & $11.99 * * *$ \\
\hline Month & 5 & $36289 * * *$ & $27244 * * *$ & $1.37 * *$ & $21.92 * * *$ & $0.03 *$ & $0.05 * *$ & $0.10 * * *$ & $0.3 * * *$ \\
\hline Location.Genotype & 28 & $5840 * * *$ & $5371 * * *$ & $0.86^{* *}$ & 0.16 & $0.57 * *$ & $0.16^{* * *}$ & $0.61 * * *$ & $0.17 * * *$ \\
\hline Season.Genotype & 14 & $3897 * * *$ & $2621 * * *$ & $0.54 * *$ & $0.52 * * *$ & $0.26^{*}$ & $0.03 * * *$ & $0.23 * * *$ & $0.04 * * *$ \\
\hline Genotype.Month & 70 & 3358 & $12863 * * *$ & $1.35^{* *}$ & $0.38 *$ & $0.22 * *$ & $0.26^{* * *}$ & $0.06 * * *$ & $0.26^{* * *}$ \\
\hline Location.Month & 10 & $10556 * * *$ & $2997 * * *$ & $1.46^{* * *}$ & $0.56^{* * *}$ & $0.73 * * *$ & $0.67 * * *$ & $0.17 * * *$ & $0.71 * * *$ \\
\hline Location.Season.Genotype & 28 & $3341 * *$ & $3569 * * *$ & $0.25^{*}$ & 0.11 & $0.24 *$ & $0.05^{* * *}$ & $0.58 * * *$ & $0.05^{* * *}$ \\
\hline Location.Genotype.Month & 140 & 1274 & 1502 & $0.55^{* *}$ & $0.32 * *$ & $0.44 * *$ & $0.22 * * *$ & $0.07 * * *$ & $0.22 * * *$ \\
\hline Season.Genotype.Month & 70 & $4777 * *$ & 1845 & $0.71 *$ & $0.08^{*}$ & $0.32 *$ & $0.05 * * *$ & $0.12 * * *$ & $0.08 * * *$ \\
\hline Error & 1208 & 2144 & 1461 & 0.47 & 0.17 & 0.26 & 0.02 & 0.02 & 0.02 \\
\hline $\mathrm{CV} \%$ & & 55.32 & 60.18 & 30.24 & 13.56 & 13.16 & 26.22 & 26.03 & 27.16 \\
\hline
\end{tabular}

Note. df: degree of freedom; *** significant at $\mathrm{P}<0.001 ; * *$ significant at $\mathrm{P}<0.01 ; *$ significant at $\mathrm{P}<0.05 ; \mathrm{CV}$ : coefficient of variation.

The results of the mean values of all traits in three locations across two seasons are presented in Figure 1. In Namulonge, (Figure 1A) resistant genotype UG 120133, had the lowest nymph count (21.99) except for NASE 13, UG 120001, UG 130038 and UG 130075 with counts of 76.55, 84.25, 76.49 and 84.89 respectively. NASE 13 and UG 120191 recorded least whitefly counts of 33.18 and 33.19 respectively (Figure 1B) but UG 130075 had the highest count (96.32). CS1-144 had the least leaf damage (0.35) and sooty mold (0.15) (Figures 1C and 1D), compared to NASE 13, UG 120001 and UG 130038 with leaf damage values of 1.66, 165 and 1.62 whereas NASE 13 and UG 130075 had sooty mold scores of 0.77 and 0.73 respectively. CS1-144 had the highest tannin content $(0.68 \mathrm{~g} / \mathrm{ml})$ (Figure 1E) and antioxidative capacity $(0.96 \mathrm{~g} / \mathrm{ml})$ (Figure $1 \mathrm{H})$ compared to NASE 13, UG 120001 and UG 130068 all with the least concentration of tannin $(0.1 \mathrm{~g} / \mathrm{ml})$. UG 130038 and UG 130075 had the least antioxidative capacity $(0.04 \mathrm{~g} / \mathrm{ml})$. UG 120133 had high amounts of flavonoids $(0.66 \mathrm{~g} / \mathrm{ml})$ (Figure $1 \mathrm{~F})$ and total phenolics $(0.92 \mathrm{~g} / \mathrm{ml})$ (Figure $1 \mathrm{G})$ while UG 130075 recorded least flavonoid and total phenolic content $(0.03 \mathrm{~g} / \mathrm{ml}$ and $0.04 \mathrm{~g} / \mathrm{ml})$ respectively.

In Kamuli, resistant genotype CS1-144 recorded lowest nymph count (24.56), whitefly count (30.59) and sooty mold (0.11), as compared to susceptible UG 130075 with values of $68.91,62.04$ and 0.64 respectively. UG 120133 had the least leaf damage (0.34), while UG 130038 had the highest score (1.24). UG 120160 had highest amounts of tannin $(0.85 \mathrm{~g} / \mathrm{ml})$ while the susceptible control, NASE 13 as well as UG 130038 recorded the lowest tannin quantities $(0.17$ and $0.19 \mathrm{~g} / \mathrm{ml})$ respectively. CS1-144 had highest concentrations of flavonoid $(0.86 \mathrm{~g} / \mathrm{ml})$, total phenolic $(0.91 \mathrm{~g} / \mathrm{ml})$ and antioxidative capacity $(0.86 \mathrm{~g} / \mathrm{ml})$. UG 130038 was among susceptible genotypes with lowest quantities of flavonoid $(0.03 \mathrm{~g} / \mathrm{ml})$, total phenolic $(0.04 \mathrm{~g} / \mathrm{ml})$ and antioxidative capacity $(0.04 \mathrm{~g} / \mathrm{ml})$.

In Kasese, UG 120160 had the least number of nymphs (50.89) except for NAM 130 and UG 130068 with highest nymph counts (116.07 and 115.54) respectively. CS1-144 had the least number of whiteflies (40.71), highest flavonoid concentration $(1.34 \mathrm{~g} / \mathrm{ml})$, total phenolic content $(1.42 \mathrm{~g} / \mathrm{ml})$ and antioxidative capacity $(1.36$ $\mathrm{g} / \mathrm{ml})$. UG 120124 recorded the least leaf damage score $(0.44)$. UG 130068 recorded the highest whitefly numbers (83.33), leaf damage (2.27), sooty mold (1.21), least flavonoid $(0.05 \mathrm{~g} / \mathrm{ml})$, total phenolic content $(0.05$ $\mathrm{g} / \mathrm{ml})$ and antioxidative capacity $(0.04 \mathrm{~g} / \mathrm{ml})$. 

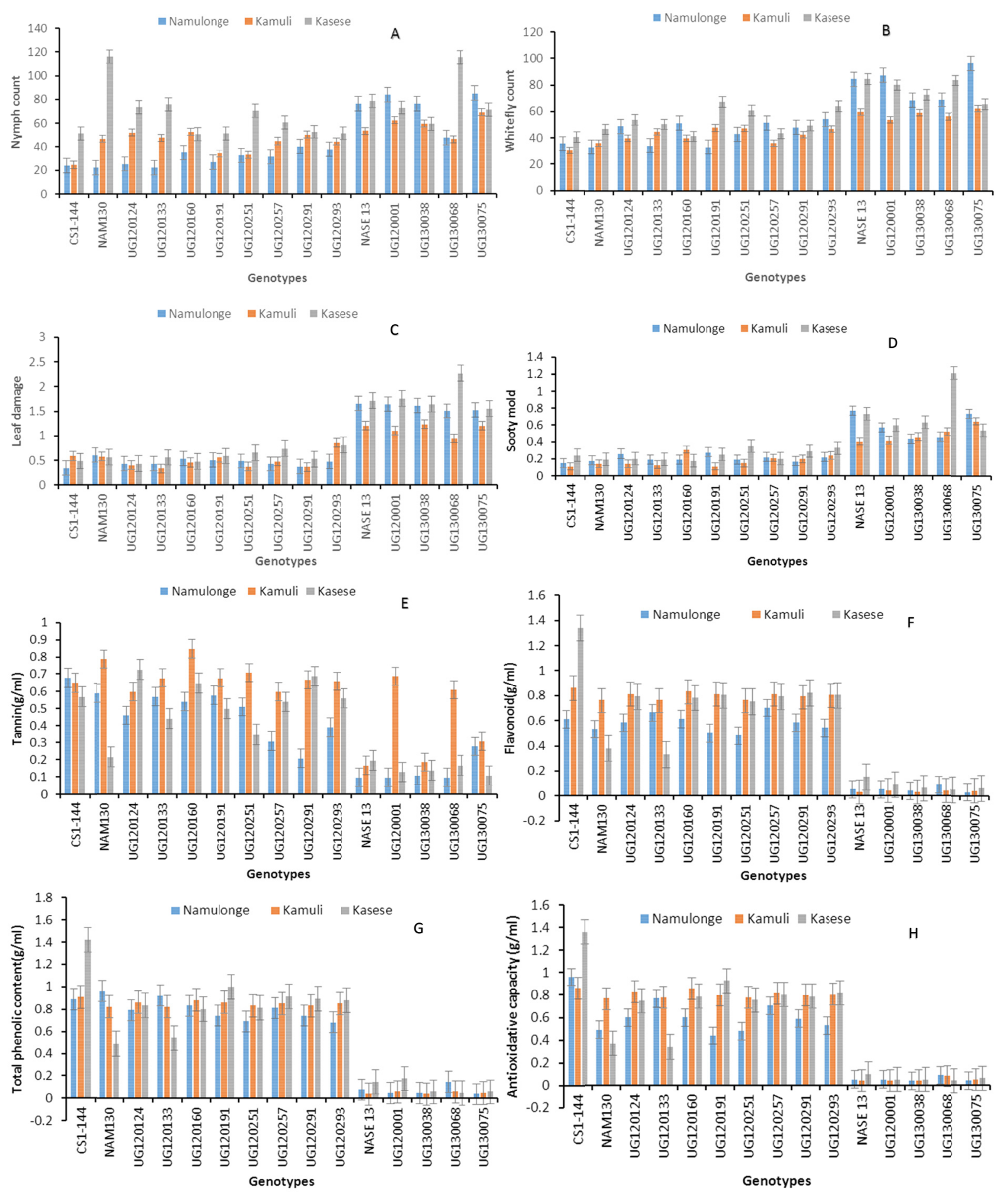

Figure 1. Means of A: nymph count, B: whitefly count, C: leaf damage, D: sooty mold, E: tannins, F: flavonoids, $\mathrm{G}$ : total phenolic content and $\mathrm{H}$ : antioxidative capacity, recorded on genotypes in three locations across two seasons

Table 3 presents mean genotypic values for nymph count, whitefly count, leaf damage, sooty mold, tannin, flavonoid, total phenolic content and antioxidative capacity per season. Among all the genotypes, resistant CS1-144 and UG 120291 had the least leaf damage scores of 0.21 and 0.22 respectively recorded in season one. Susceptible UG 120001 had highest leaf damage scores in season one and season two of 1.89 and 2.25 respectively and UG 130068 had 1.82 and 1.67 in season one and two respectively. CS1-144 had the highest 
value of flavonoid concentration $(1.05 \mathrm{~g} / \mathrm{ml})$ among all the genotypes in season one compared to season two and had lowest number of whitefly in both seasons. In both seasons, UG 120124 a resistant genotype had the highest tannin concentration $(0.46$ and $0.45 \mathrm{~g} / \mathrm{ml})$ in season one and two respectively, total phenolic content $(0.60$ and $0.58 \mathrm{~g} / \mathrm{ml})$ and antioxidative capacity $(0.53$ and $0.51 \mathrm{~g} / \mathrm{ml})$. Susceptible UG 130038 had the least tannin of 0.21 $\mathrm{g} / \mathrm{ml}$ and $0.23 \mathrm{~g} / \mathrm{ml}$ in season one and two respectively while UG $130075 \mathrm{had} 0.04 \mathrm{~g} / \mathrm{ml}$ for total phenolic content in season one and two respectively and 0.05 and $0.04 \mathrm{~g} / \mathrm{ml}$ for antioxidative capacity in season one and two respectively.

Table 3. Mean nymph count, whitefly count, leaf damage, sooty mold, tannin, flavonoid, total phenolic content and antioxidative capacity of genotypes for two seasons across locations

\begin{tabular}{|c|c|c|c|c|c|c|c|c|c|c|c|c|c|c|c|c|}
\hline \multirow{2}{*}{$\begin{array}{l}\text { Parameter } \\
\text { Season }\end{array}$} & \multicolumn{2}{|c|}{$\begin{array}{l}\text { Nymph } \\
\text { count }\end{array}$} & \multicolumn{2}{|c|}{$\begin{array}{l}\text { Whitefly } \\
\text { count }\end{array}$} & \multicolumn{2}{|c|}{$\begin{array}{l}\text { Leaf } \\
\text { damage }\end{array}$} & \multicolumn{2}{|c|}{$\begin{array}{l}\text { Sooty } \\
\text { mold }\end{array}$} & \multicolumn{2}{|c|}{$\begin{array}{l}\text { Tannin } \\
(\mathrm{g} / \mathrm{ml})\end{array}$} & \multicolumn{2}{|c|}{$\begin{array}{l}\text { Flavonoid } \\
(\mathrm{g} / \mathrm{ml})\end{array}$} & \multicolumn{2}{|c|}{$\begin{array}{l}\text { Total phenolic } \\
\text { content }(\mathrm{g} / \mathrm{ml})\end{array}$} & \multicolumn{2}{|c|}{$\begin{array}{l}\text { Antioxidative } \\
\text { capacity }(\mathrm{g} / \mathrm{ml})\end{array}$} \\
\hline & 1 & 2 & 1 & 2 & 1 & 2 & 1 & 2 & 1 & 2 & 1 & 2 & 1 & 2 & 1 & 2 \\
\hline CS1-144 & 30.08 & 36.53 & 31.20 & 40.02 & 0.2 & 0.52 & 0.16 & 0.18 & 0.45 & 0.44 & 1.05 & 0.83 & 0.57 & 0.52 & 0.49 & 0.42 \\
\hline NAM130 & 51.28 & 71.97 & 35.43 & 42.06 & 0.2 & 0.67 & 0.07 & 0.27 & 0.42 & 0.42 & 0.55 & 0.57 & 0.53 & 0.53 & 0.46 & 0.46 \\
\hline UG120124 & 49.54 & 51.01 & 43.73 & 51.64 & 0.5 & 0.52 & 0.20 & 0.20 & 0.46 & 0.45 & 0.76 & 0.7 & 0.6 & 0.58 & 0.53 & 0.51 \\
\hline UG120133 & 42.87 & 54.12 & 31.70 & 54.89 & 0.5 & 0.67 & 0.12 & 0.21 & 0.44 & 0.44 & 0.63 & 0.54 & 0.57 & 0.52 & 0.5 & 0.5 \\
\hline UG120160 & 44.93 & 47.44 & 28.99 & 59.83 & 0.6 & 0.5 & 0.23 & 0.23 & 0.44 & 0.42 & 0.73 & 0.75 & 0.56 & 0.54 & 0.5 & 0.49 \\
\hline UG120191 & 28.78 & 46.05 & 36.31 & 62.74 & 0.8 & 0.78 & 0.20 & 0.22 & 0.41 & 0.4 & 0.66 & 0.75 & 0.52 & 0.51 & 0.47 & 0.46 \\
\hline UG120251 & 48.20 & 42.65 & 47.22 & 54.00 & 0.6 & 0.56 & 0.16 & 0.31 & 0.39 & 0.37 & 0.73 & 0.59 & 0.49 & 0.47 & 0.44 & 0.42 \\
\hline UG120257 & 51.43 & 40.03 & 40.71 & 47.14 & 0.4 & 0.72 & 0.20 & 0.23 & 0.36 & 0.35 & 0.8 & 0.74 & 0.44 & 0.39 & 0.4 & 0.36 \\
\hline UG120291 & 51.87 & 43.90 & 30.94 & 62.84 & 0.2 & 0.44 & 0.16 & 0.28 & 0.33 & 0.31 & 0.73 & 0.72 & 0.35 & 0.31 & 0.53 & 0.29 \\
\hline UG120293 & 53.77 & 35.63 & 43.91 & 66.48 & 0.6 & 0.61 & 0.24 & 0.28 & 0.28 & 0.26 & 0.68 & 0.75 & 0.26 & 0.2 & 0.24 & 0.17 \\
\hline NASE 13 & 77.75 & 61.54 & 65.08 & 87.47 & 2.1 & 1.5 & 0.53 & 0.74 & 0.41 & 0.42 & 0.12 & 0.04 & 0.52 & 0.53 & 0.46 & 0.47 \\
\hline UG120001 & 64.89 & 81.71 & 78.99 & 68.74 & 1.9 & 2.25 & 0.55 & 0.52 & 0.43 & 0.45 & 0.08 & 0.04 & 0.56 & 0.58 & 0.49 & 0.51 \\
\hline UG130038 & 69.22 & 61.22 & 65.42 & 68.34 & 1.1 & 1.5 & 0.42 & 0.60 & 0.21 & 0.23 & 0.04 & 0.04 & 0.07 & 0.07 & 0.05 & 0.05 \\
\hline UG130068 & 63.08 & 76.85 & 60.40 & 78.86 & 1.8 & 1.67 & 0.67 & 0.79 & 0.25 & 0.23 & 0.06 & 0.06 & 0.08 & 0.07 & 0.05 & 0.05 \\
\hline UG130075 & 88.84 & 61.02 & 82.31 & 66.87 & 1.4 & 1.23 & 0.60 & 0.66 & 0.24 & 0.25 & 0.05 & 0.04 & 0.04 & 0.04 & 0.05 & 0.04 \\
\hline $\operatorname{LSD}(0.05)$ & 17.48 & 30.28 & 14.43 & 25.00 & 0.3 & 0.24 & 0.16 & 0.27 & 0.26 & 0.07 & 0.06 & 0.05 & 0.08 & 0.06 & 0.06 & 0.05 \\
\hline
\end{tabular}

Note. LSD: least significant difference at $5 \%$.

\subsection{Additive Main Effects and Multiplicative Interactions Analysis of Traits Measured}

The AMMI analysis of variance for nymph count, whitefly count, leaf damage, sooty mold, tannin, flavonoid total phenolic content and antioxidative capacity, of the 15 genotypes tested in three locations and six months (18 environments) is shown in Table 4. The interaction terms of IPCA1 and IPCA2 were significantly $\mathrm{P}<0.001$ different at for nymph count, leaf damage, flavonoid, total phenolic content and antioxidative capacity. The first linear interaction term (IPCA1) of the AMMI antioxidative analysis, accounted for $88.8 \%$ of the GxE sum of squares, and the second accounted for $6.79 \%$ using 30 and 28 degree of freedom $(d f)$ respectively. The two first bilinear terms accounted for $95.59 \%$ of the $\mathrm{G} \times \mathrm{E}$ sum of squares and used 58 of the $238 d f$ available in the interaction. Genotypes, environments and GEI as treatments explained $67.3 \%$ for tannins, $84.81 \%$ for flavonoids, $86.15 \%$ for total phenolic content and $84.5 \%$ for antioxidative capacity of the total variation. The genotypes explained $46.3 \%$ for tannins, $53.02 \%$ for flavonoids, $48.86 \%$ for total phenolic content and $58.5 \%$ for antioxidative capacity while the environment explained $11.5 \%, 19.62 \%, 23.7 \%$ and $17.9 \%$ for tannin, flavonoid, total phenolic content and antioxidative capacity respectively. The Genotype by Environment interactions (GEI) at significance $\mathrm{P}<0.001$ explained $17.1 \%$ for nymph count, $6.1 \%$ for sooty mold, $12.19 \%$ for flavonoid, $13.5 \%$ for total phenolics, $8.1 \%$ for antioxidative capacity, at $\mathrm{P}<0.05$ explained $8.6 \%$ for whitefly count, $9.7 \%$ for leaf damage and $9.5 \%$ for tannin. 
Table 4. AMMI analysis of variance for nymph count, whitefly count, damage, sooty mold, tannin, flavonoid, total phenolic content and antioxidative capacity of cassava genotypes, Uganda

\begin{tabular}{|c|c|c|c|c|c|c|c|c|c|c|c|c|c|c|c|c|c|}
\hline SOV & df & $\mathrm{NC}$ & $\begin{array}{l}\operatorname{Exp} \\
(\%)\end{array}$ & WC & $\begin{array}{l}\operatorname{Exp} \\
(\%)\end{array}$ & LD & $\begin{array}{l}\operatorname{Exp} \\
(\%)\end{array}$ & SM & $\begin{array}{l}\operatorname{Exp} \\
(\%)\end{array}$ & $\mathbf{T}$ & $\begin{array}{l}\operatorname{Exp} \\
(\%)\end{array}$ & $\mathbf{F}$ & $\begin{array}{l}\operatorname{Exp} \\
(\%)\end{array}$ & TPC & $\begin{array}{l}\operatorname{Exp} \\
(\%)\end{array}$ & $\mathrm{AC}$ & $\begin{array}{l}\operatorname{Exp} \\
(\%)\end{array}$ \\
\hline Total & 1619 & 0.4 & & 2297 & & 0.9 & & 0.3 & & 0.3 & & 0.2 & & 0.195 & & 244.7 & \\
\hline Treatments & 269 & $0.9^{* * *}$ & 78.6 & $3409^{* * *}$ & 70.9 & $1.9^{* * *}$ & 53.3 & $0.9^{* * *}$ & 44.8 & $0.5^{* * *}$ & 67.3 & $0.7^{* * *}$ & 84.81 & $0.937^{* * *}$ & 86.15 & $206.9^{* * *}$ & 84.5 \\
\hline Genotypes (G) & 14 & $4.4^{* * *}$ & 23.2 & $21012^{* * *}$ & 22.2 & $25.2^{* * *}$ & 25.7 & $4.4^{* * *}$ & 28.5 & $3.4^{* * *}$ & 46.3 & $11.8^{* * *}$ & 53.02 & $15.566^{* * *}$ & 48.86 & $167.8^{* * *}$ & 53.5 \\
\hline Environments (E) & 17 & $6.9^{* *}$ & 38.3 & $12232^{* *}$ & 40.1 & $2.1^{* *}$ & 17.9 & $6.9^{* * *}$ & 10.2 & $1.2^{*}$ & 11.5 & $0.5^{* * *}$ & 19.62 & $0.162^{* * *}$ & 23.7 & $9.9^{* * *}$ & 22.9 \\
\hline Blocks & 36 & $2.8^{* * *}$ & & $17931^{* * *}$ & & $9.8^{* * *}$ & & $2.8^{* * *}$ & & $6.2^{* * *}$ & & 0.02 & & 0.052 & & $1.7^{* * *}$ & \\
\hline GEI & 238 & $0.3^{* * *}$ & 17.1 & $1743^{*}$ & 8.6 & $0.5^{*}$ & 9.76 & $0.3^{* * *}$ & 6.1 & $0.3^{*}$ & 9.5 & $0.1^{* * *}$ & 12.19 & $0.132^{* * *}$ & 13.5 & $29.2^{* * *}$ & 8.1 \\
\hline IPCA1 & 30 & $1.1^{* * *}$ & 12.6 & $5563^{* * *}$ & 40.2 & $1.6^{* * *}$ & 56.61 & $1.1^{* * *}$ & 47.2 & $1.7^{* * *}$ & 68.2 & $0.5^{* * *}$ & 60.58 & $0.562^{* * *}$ & 53.71 & $16.7^{* * *}$ & 88.8 \\
\hline IPCA2 & 28 & $0.8^{* * *}$ & 11.7 & $2677^{* *}$ & 18.1 & $0.9^{* * *}$ & 25.76 & 0.7 & 28.8 & $0.5^{*}$ & 16.7 & $0.2^{* * *}$ & 19 & $0.216^{* * *}$ & 19.24 & $5.7^{* * *}$ & 6.79 \\
\hline Residuals & 180 & 0.1 & & 961 & & 0.3 & & 0.1 & & 0.1 & & 0.03 & & 0.047 & & 6.8 & \\
\hline Error & 1314 & 0.1 & & 1640 & & 0.5 & & 0.2 & & 0.3 & & 0.02 & & 0.048 & & 36.2 & \\
\hline
\end{tabular}

Note. * significant at $\mathrm{P}<0.05 ; * *$ significant at $\mathrm{P}<0.01 ; * * *$ significant at $\mathrm{P}<0.001$; SOV: Sources of variation, df: degree of freedom, NC: Nymph count; Exp: Explained percentage sum of squares; WC: Whitefly count; LD: leaf damage; SM: sooty mold; T: Tannin; F: Flavonoid; TPC: Total Phenolic Content; AC: Antioxidative capacity; GEI: Genotype $\times$ Environment Interactions.

Environments were ranked based on AMMI stability values (ASV) for antioxidative capacity (Table 5). Environments and genotypes with least ASV scores were considered as the most stable. Environment Namulonge month 1 (NM1) had the least ASV score of -0.512 with antioxidative capacity mean of 0.629 . The four genotypes corresponding to the ASV score were UG 120257, UG 120191, UG 120291 and UG 120251. In terms of genotypic performance, genotypes UG 120133, NAM 130, CS1-144 and UG 120191 had high antioxidative capacities with mean of 0.651 .

Table 5. First four genotype selections based on ASV of antioxidative capacity in each environment

\begin{tabular}{llllllllll}
\hline \multirow{2}{*}{ Rankings } & \multirow{2}{*}{ Environment } & Mean & ASV & IPCAe[1] & IPCAe[2] & \multicolumn{3}{c}{ Genotypes } \\
\cline { 7 - 10 } & & & & & & $\mathbf{1}$ & $\mathbf{2}$ & $\mathbf{3}$ & $\mathbf{4}$ \\
2 & KM2 & 0.545 & 0.362 & 0.23 & -0.36 & UG120133 & NAM130 & UG120160 & CS1-144 \\
3 & KM1 & 0.563 & 0.347 & -0.43 & 0.18 & NAM130 & UG120160 & UG120133 & UG120257 \\
4 & KM6 & 0.487 & 0.347 & -0.33 & 0.25 & NAM130 & UG120257 & UG120293 & UG120124 \\
5 & KM4 & 0.567 & 0.298 & -0.42 & -0.04 & UG120133 & NAM130 & CS1-144 & UG120191 \\
6 & KM5 & 0.651 & 0.254 & -0.34 & 0.05 & UG120133 & NAM130 & CS1-144 & UG120191 \\
7 & KM3 & 0.555 & 0.206 & -0.35 & 0.004 & UG120133 & CS1-144 & UG120191 & NAM130 \\
8 & KAM4 & 0.648 & 0.136 & 0.10 & -0.19 & CS1-144 & UG120133 & UG120191 & UG120160 \\
9 & KAM6 & 0.552 & 0.13 & 0.14 & -0.24 & CS1-144 & UG120160 & NANM130 & UG120257 \\
10 & KAM5 & 0.584 & 0.119 & 0.10 & -0.32 & CS1-144 & UG120257 & UG120160 & NAM130 \\
11 & KAM3 & 0.604 & 0.102 & 0.17 & -0.26 & CS1-144 & UG120257 & UG120160 & UG120191 \\
12 & KAM2 & 0.558 & 0.09 & 0.14 & -0.31 & CS1-144 & UG120257 & UG120160 & UG120124 \\
13 & NM5 & 0.557 & 0.057 & 0.10 & 0.14 & CS1-144 & UG120257 & UG120160 & UG120191 \\
14 & NM3 & 0.592 & -0.293 & 0.29 & 0.16 & CS1-144 & UG120191 & UG120291 & UG120257 \\
15 & KAM1 & 0.592 & -0.352 & 0.23 & -0.36 & CS1-144 & UG120257 & UG120293 & UG120291 \\
16 & NM6 & 0.585 & -0.364 & 0.09 & 0.12 & CS1-144 & UG120191 & UG120291 & UG120257 \\
17 & NM4 & 0.580 & -0.446 & 0.28 & 0.10 & CS1-144 & UG120257 & UG120293 & UG120291 \\
18 & NM2 & 0.651 & -0.482 & 0.45 & 0.29 & CS1-144 & UG120124 & UG120291 & UG120257 \\
\hline Note. & NM1 & 0.629 & -0.512 & 0.35 & 0.47 & UG120257 & UG120191 & UG120251 & UG120124 \\
\hline
\end{tabular}

Note. ASV: AMMI stability value; IPCA1: Interaction principal component 1; IPCA2: Interaction principal component.

The AMMI Interaction Principal Component Analyses (IPCA) scores for both the genotypes and environments plotted against total antioxidative capacity are shown in Figure 2. The graph space was divided into 4 quadrants, from environments having genotypes with lower antioxidative capacity in quadrant 1 and 4 to high in quadrant 2 
and 3. The first principal component (IPCA 1) and the second (IPCA 2) accounted for $88.88 \%$ and $6.679 \%$ respectively. AMMI biplot analysis for antioxidative capacity of the 15 genotypes tested at three locations in the present investigation showed that the relative variability due to genotypes was more than the variability due to locations as indicated by the distribution as well position occupied by the 15 genotypes and 18 environments on biplot display (Figure 2). CS1-144 and UG 120191 had high antioxidative capacity as they were at a longer distance from the midpoint however, the distance from the axis indicated the genotypes were very interactive with the environment. The angles between the genotype and environment vectors determine the nature of the interaction as it is positive for acute angles, negligible for right angles, and negative for obtuse angles. At the same time, the angle formed by the vectors of two environments provided an estimate of their correlation. UG 120251 was more stable as it was closer to the midpoint axis and close to all environments. Namulonge was more stable for antioxidative capacity as it was closer to the midpoint on the right axis. Further, Kasese (KA) and Kamuli (KM) were environments yielding high antioxidative capacity. Kasese and Namulonge (NM) showed similar environmental characteristics compared to Kamuli.

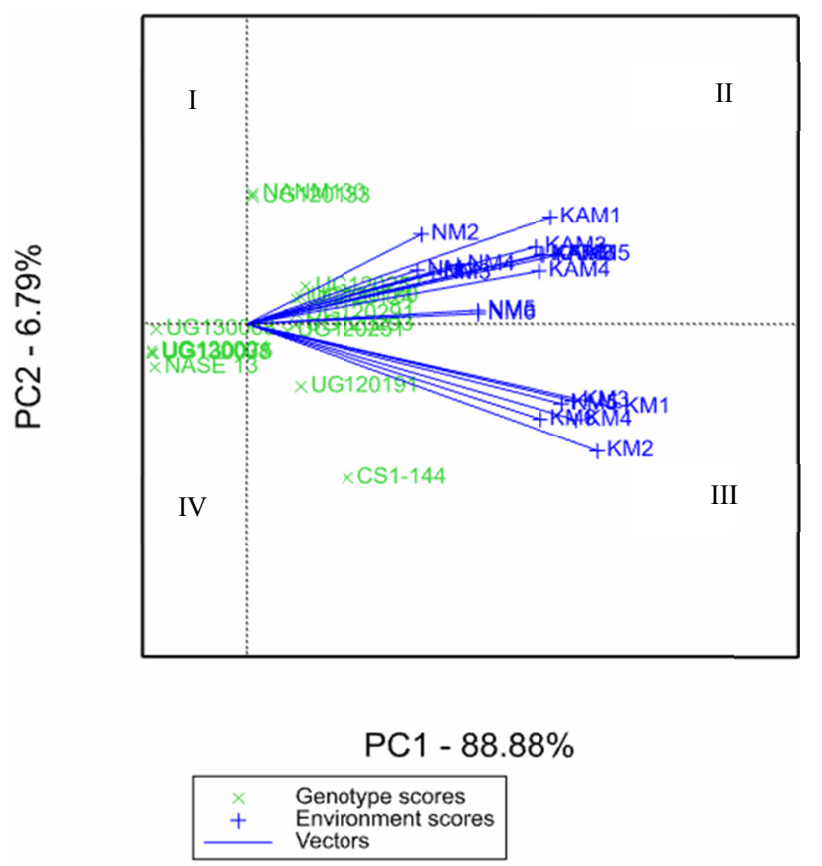

Figure 2. AMMI biplot for antioxidative capacity of 15 genotypes in 18 environments using genotype by environment score

\subsection{Inter-relationships of Bemisia tabaci With Secondary Metabolite and Abiotic Factors in Cassava}

The results of correlation analysis for all the traits are presented in Table 6 . Whitefly and sooty mold were significantly $(\mathrm{P}<0.01)$ positively associated to leaf damage $(\mathrm{r}=0.578$ and $\mathrm{r}=0.504)$ respectively. Nymph count was significantly $(\mathrm{P}<0.05)$ correlated to the leaf damage $(\mathrm{r}=0.46)$.

Tannin, total phenolic content were significantly $(\mathrm{P}<0.01)$ negatively related to leaf damage $(\mathrm{r}=-0.438)$ and $(\mathrm{r}$ $=-0.497)$. The antioxidative capacity was significantly $(\mathrm{P}<0.001)$ negatively associated to leaf damage $(\mathrm{r}=$ -0.667). The minimum temperature and maximum temperature showed significant $(\mathrm{P}<0.001)$ positive correlation to leaf damage with $\mathrm{r}=0.627$ and $\mathrm{r}=0.673$ respectively. Rainfall had significant $\mathrm{P}<0.05$ negative association to leaf damage $(\mathrm{r}=-0.265)$. 
Table 6. Correlation coefficients of traits across seasons and locations

\begin{tabular}{|c|c|c|c|c|c|c|c|c|c|c|c|}
\hline & $\begin{array}{l}\text { Nymph } \\
\text { count }\end{array}$ & $\begin{array}{l}\text { Leaf } \\
\text { damage }\end{array}$ & $\begin{array}{l}\text { Whitefly } \\
\text { count }\end{array}$ & $\begin{array}{l}\text { Sooty } \\
\text { mold }\end{array}$ & $\begin{array}{l}\text { Tannin } \\
(\mathrm{g} / \mathrm{ml})\end{array}$ & $\begin{array}{l}\text { Antioxidative } \\
\text { capacity } \\
(\mathrm{g} / \mathrm{ml})\end{array}$ & $\begin{array}{l}\text { Flavonoid } \\
(\mathrm{g} / \mathrm{ml})\end{array}$ & $\begin{array}{l}\text { Total } \\
\text { phenolic } \\
\text { content } \\
(\mathrm{g} / \mathrm{ml})\end{array}$ & $\begin{array}{l}\text { Temperature } \\
(\min )\left({ }^{\circ} \mathrm{C}\right)\end{array}$ & $\begin{array}{l}\text { Temperature } \\
(\max )\left({ }^{\circ} \mathrm{C}\right)\end{array}$ & $\begin{array}{l}\text { Rainfall } \\
(\mathrm{mm})\end{array}$ \\
\hline Nymph count & - & & & & & & & & & & \\
\hline Leaf damage & $0.46^{*}$ & - & & & & & & & & & \\
\hline Whitefly count & 0.391 & $0.578^{* *}$ & - & & & & & & & & \\
\hline Sooty mold & 0.105 & $0.504^{* *}$ & $0.552^{* *}$ & - & & & & & & & \\
\hline Tannin $(\mathrm{g} / \mathrm{ml})$ & -0.123 & $-0.438^{* *}$ & $-0.119^{*}$ & -0.123 & - & & & & & & \\
\hline $\begin{array}{l}\text { Antioxidative } \\
\text { capacity }(\mathrm{g} / \mathrm{ml})\end{array}$ & -0.137 & $-0.667^{* * *}$ & $-0.181^{*}$ & $-0.248^{* * *}$ & $0.272^{* * *}$ & - & & & & & \\
\hline Flavonoid $(\mathrm{g} / \mathrm{ml})$ & -0.13 & $-0.327^{*}$ & $-0.156^{*}$ & $-0.227^{* * *}$ & $0.256^{*}$ & $0.895^{* * *}$ & - & & & & \\
\hline $\begin{array}{l}\text { Total phenolic } \\
\text { content }(\mathrm{g} / \mathrm{ml})\end{array}$ & -0.135 & $-0.497^{* *}$ & $-0.142^{*}$ & $-0.2208^{* *}$ & $0.243^{* * *}$ & $0.83^{* * *}$ & $0.797^{*}$ & - & & & \\
\hline $\begin{array}{l}\text { Temperature } \\
(\min )\left({ }^{\circ} \mathrm{C}\right)\end{array}$ & -0.158 & $0.627^{* * *}$ & $0.738^{* * *}$ & $0.061^{* * *}$ & $0.094^{*}$ & $0.68^{* * *}$ & $0.591^{*}$ & $0.717^{* *}$ & - & & \\
\hline $\begin{array}{l}\text { Temperature } \\
(\max )\left({ }^{\circ} \mathrm{C}\right)\end{array}$ & 0.282 & $0.673^{* * *}$ & $0.705^{* * *}$ & $0.037^{* *}$ & $0.132^{* *}$ & $0.751^{* * *}$ & $0.724^{* *}$ & $0.910^{* * *}$ & $0.685^{* * *}$ & - & \\
\hline Rainfall (mm) & 0.113 & -0.265 & $-0.75^{* *}$ & -0.457 & -0.084 & $-0.49^{* *}$ & $-0.376^{*}$ & 0.517 & $0.639^{* * *}$ & $0.581^{* *}$ & - \\
\hline
\end{tabular}

Note. * Significant at $\mathrm{P}<0.05 ; * *$ Significant at $\mathrm{P}<0.01$ (two-sided test).

The results of a multiple linear regression analysis to predict the overall contribution of traits measured to leaf damage are presented in Table 7 . The antioxidative capacity showed significant $(\mathrm{P}<0.001)$ negative association to leaf damage $(\beta=-0.59)$ and $\mathrm{R}^{2}=0.228$. The total phenolic content was significantly $(\mathrm{P}<0.01)$ negatively related to leaf damage $(\beta=-0.364)$ and $\mathrm{R}^{2}=0.117$. The antioxidative capacity predicted lower leaf damage more, based on higher negative regression estimate $(\beta=-0.59)$, as compared to maximum, minimum temperature and rainfall with $\beta=0.154, \beta=0.066, \beta=-0.002$ respectively. The total sample correlation coefficient was $r=0.81$ and indicated $65.61 \%$ of the leaf damage was accounted for by the whitefly count, antioxidative capacity and temperature.

Table 7. Multiple regression analyses estimates for tannin, antioxidative capacity, flavonoid, phenolics and environmental factors among genotypes

\begin{tabular}{|c|c|c|c|c|}
\hline Parameter & $\begin{array}{l}\text { Regression coefficient } \\
\text { estimate }\end{array}$ & $\begin{array}{l}\text { Standard error } \\
\text { of estimate }\end{array}$ & $\mathrm{t}(\mathbf{1 6 1 1})$ & $\mathbf{R}^{2}$ \\
\hline Constant & $0.531 * * *$ & 0.040 & 12.520 & \\
\hline Nymph_count & $0.003 *$ & 0.0003 & 16.461 & 0.046 \\
\hline Whitefly_count & $0.476^{* * *}$ & 0.0004 & 6.950 & 0.163 \\
\hline Sooty_mold & $0.005^{*}$ & 0.036 & 13.102 & 0.065 \\
\hline Tannin $(\mathrm{g} / \mathrm{ml})$ & $-0.058^{*}$ & 0.132 & -0.446 & 0.031 \\
\hline Flavonoids (g/ml) & $0.151 * *$ & 0.311 & 0.480 & 0.109 \\
\hline Total Phenolic Content $(\mathrm{g} / \mathrm{ml})$ & $-0.364 * * *$ & 0.091 & 1.812 & 0.117 \\
\hline Antioxidative capacity $(\mathrm{g} / \mathrm{ml})$ & $-0.595 * * *$ & 0.104 & -5.743 & 0.228 \\
\hline Temperature (min) & $0.066^{* * *}$ & 0.175 & 0.376 & 0.098 \\
\hline Temperature (max) & $-0.154 * *$ & 0.032 & -4.751 & 0.124 \\
\hline Rainfall (mm) & -0.002 & 0.002 & -0.870 & 0.0016 \\
\hline
\end{tabular}

Note. Significance of regression model at $\mathrm{P}<0.001$ from 0 . Correlation coefficient variance explained around the mean $=0.548 ; * * *$ Significant at $\mathrm{P}<0.001 ; * *$ Significant at $\mathrm{P}<0.01 ; *$ Significant at $\mathrm{P}<0.05$.

\section{Discussion}

4.1 Genotype by Environment Effect on Nymph Count, Whitefly Count, Leaf Damage, Sooty Mold, Tannin, Flavonoid, Total Phenolic Content and Antioxidative Capacity

The genotypes varied significantly $(\mathrm{P}<0.001)$ for all traits measured in different environments, relating to the significant genotype by location, genotype by season and genotype by location by season interactions (Table 2 ). 
The interaction effects implied that $B$. tabaci and secondary metabolite concentrations depended on climatic conditions in different locations, in particular seasonal temperature and rainfall variations (Table 1). According to Ballhorn et al. (2011), growing conditions influence the genotypes producing metabolite variations due to differing function and expression of genes regulating the traits. Similarly, temperature and rainfall variations were reported to affect plant response to whitefly (Bemisia tabaci) and plant secondary metabolites across environments in aspen juvenile trees (Jamieson et al., 2017). Further, in agreement with Mtunguja, Laswai, Kanju, Ndunguru, and Muzanila (2016) although GXE had significant effects for cyanide content in cassava varieties in different environments in Tanzania, genotypes had the highest significant effect.

The mean variation among genotypes for all the traits across Kamuli, Kasese, and Namulonge (Figure 1) showed that although all three locations were whitefly hotspots, the genotypes responded differently due to varying locational factors. In particular, Namulonge and Kasese which were at lower altitudes compared to Kamuli, had higher temperatures (Table 1), recorded the lowest mean leaf damage and highest antioxidative capacity in genotypes such as CS1-144. Burns et al. (2012) reported that different cassava genotypes behaved differently for cyanide in different locations in Mozambique. Further, the findings are in agreement with Caffrey et al. (2013), who reported similar temperature differences among locations in Kamuli, Kasese and Namulonge. Increase in altitude is documented to lower atmospheric temperatures (Caffrey et al., 2013) and that for every $100 \mathrm{~m}$ increase in altitude there is a $0.7{ }^{\circ} \mathrm{C}$ decrease in temperature (Linacre \& Geerts, 1997). According to literature, low temperatures reduce whitefly action due to decreased cellular activity, increase plant antioxidants which further decrease insect movement, feeding and reproduction (CIAT, 2011).

The mean value of all traits among the genotypes varied across seasons (Table 3). Concentrations in total phenolics and antioxidative capacity were highest among some genotypes such as UG 120124 and UG 120133 in season one than season two due to higher season one maximum and minimum mean temperatures (Table 1). The temperatures were inconsistent across seasons for example, Kasese recorded a maximum temperature of $31.89{ }^{\circ} \mathrm{C}$ in season one and $29.23{ }^{\circ} \mathrm{C}$ in season two which can be attributed to varying rainfall amounts in the particular seasons with recorded low amounts of $56.10 \mathrm{~mm}$ in season one and a high of $72.42 \mathrm{~mm}$ in season two. Rainfall variations and prevailing wind direction have been reported to alter temperatures from season to season and location to location (Linacre \& Geerts, 1997). Temperatures ranged between $17.06{ }^{\circ} \mathrm{C}$ to $31.53{ }^{\circ} \mathrm{C}$ in season one and $16.36{ }^{\circ} \mathrm{C}$ to $28.51^{\circ} \mathrm{C}$ in season two indicating a higher increase in temperature and metabolite in season one for example, UG 120291 had $0.53 \mathrm{~g} / \mathrm{ml}$ of antioxidative capacity in season one and $0.29 \mathrm{~g} / \mathrm{ml}$ in season two. Elevated temperatures increase the production of metabolites in plants, through the activation of catalytic enzymes which are part of the phenolic and antioxidative capacity pathways (Hasanuzzaman et al., 2009). The average rate of enzymatic reactions involved in antioxidative capacity increases twofold with every $10{ }^{\circ} \mathrm{C}$ increase in temperature (Matilla, 2012).

Further the genotypes showed that with high mean temperature, a corresponding increase in nymph, whitefly count and leaf damage occurred. Concomitant increase in flavonoid, tannin, phenolics and antioxidative capacity in genotypes such as UG 120251 suggested the antioxidative role played in protecting plants against high temperature effects as reported by Pisoschi, Pop, Cimpeanu, and Predoi, (2016).

\subsection{Stability Performance of the Genotypes, Environmental Factors and Secondary Metabolites}

The significance of genotypic and environmental variances of the metabolites in the AMMI analysis (Table 5) indicated that resistance is a complex polygenic trait influenced by both genotype and environment factors. The results implied that genotype rankings across environments changed due to the variation in correlation between the genotype and phenotype, making it difficult to select superior genotypes across environments thus most genotype recommendations would be made for specific environments. Metabolite variances have been reported to occur due to plants detecting and responding to specific environmental signals via various pathways including increase in antioxidative capacity (Huber \& Bauerle, 2016). Similar results were reported in wheat where genotype and environment were significantly affecting flavonoid, phenolic and antioxidative capacity (Shamloo et al., 2017).

In the current study, the contribution of the genotypes to the total variation was higher than the effect of the environment and genotype by environment interactions (GEI) for all metabolites tested, leaf damage and sooty mold except for nymph and whitefly count (Table 5). The genotypes were diverse and caused the greatest variation in metabolite traits measured, indicating presence of additive gene action. The implication of the results were, that if judicious selection among these genotypes was made, significant genetic gains could be feasible and provide an opportunity for remarkable improvement among the traits. The results agree with work conducted on 
tomato where metabolite-mediated resistance to $B$. tabaci was more controlled by genotypic factors (Van Doorn \& Vos, 2013).

The environmental effects being higher for variations in nymph and whitefly count can be attributed to high temperatures increasing numbers of $B$. tabaci activity via stylet piercing the cassava leaves causing high cell injury observed as leaf damage and triggers plant metabolite changes (Table 4). The behavioral response of $B$. tabaci to environment is also reported by CIAT, (2011). Further, a high explained environmental variance of $23.7 \%$ and $22.9 \%$ in total phenolic content and antioxidative capacity respectively (Table 5), suggested that with polygenic action of the various pathways leading to antioxidative capacity, environmental factors are likely to play a part in affecting response. The higher insect feeding, for example, in Kamuli led to increased concentrations of total phenolic and antioxidative capacity. Leaf injury has been reported to activate the phenylalanine (PAL) pathway, eventually releasing high amounts of tannins, total phenolics and increasing antioxidative capacity (Kerchev et al., 2012). This confirms that changes in multiple environmental factors may interact with plants, potentially resulting in additive (Carriero et al., 2016), synergistic (Zhang et al., 2009) or antagonistic (Kivimäenpää, Ghimire, Sutinen, Halkio, Kasurinen, \& Holopainen, 2016) effects on plants and insects.

The rankings in AMMI showed the first four genotypes that were stable for antioxidative capacity in various environments (Table 5). The most stable genotypes with least ASV scores were UG 120257, UG 120191, UG 120251 and UG 120124 with a high mean antioxidative capacity of 0.629 in Namulonge. Genotypes CS1-144, UG 120133, NAM 130, and UG 120191 had least stability with mean antioxidative capacity of 0.545 in Kamuli. The least stable environment was in Kamuli (Figure 2) which can be atttributed to higher difference between the maximum and minimum temperature across seasons of $29.84{ }^{\circ} \mathrm{C}$ than that of Namulonge $\left(25.31{ }^{\circ} \mathrm{C}\right)$ and Kasese $\left(24.73^{\circ} \mathrm{C}\right)$. Similar rankings have been used in a GXE study of shootfly in sorghum (Aruna et al., 2011).

A selection of resistant genotypes was made on adaptability of genotypes based on mean genotypic performance (Table 3), the first interaction principal component axis (IPCA1) (Figure 2) and stable genotypes based on ASV (Table 5). Five genotypes CS1-144, UG 120291, UG 120124, UG 120257 and UG 120160 were thus identified. The genotypes exhibited consistent performance, stability and adaptability across the two seasons and three locations. The possibility of selecting genotypes that are stable within a wide range of environments is due to genomes rapidly responding by selectively regulating the expression of specific genes (Okoth, Rose, Sila, \& Viljoen, 2017) in response to environmental changes (Hasanuzzaman et al., 2009). The results agree with Ballhorn et al. (2011), where similar selections were made in lima bean studied for biochemical (protein, HCN) responses infested with bean beetle under altered abiotic factors.

\subsection{Cassava Interactions and Defense Mechanisms Associated to Bemisia tabaci and Abiotic Factors}

The correlation analysis (Table 6) showed that tannin, flavonoid, and total phenolics were highly associated ( $\mathrm{r}=$ $0.272, r=0.895$ and $r=0.83$ respectively) with the antioxidative capacity. The correspondence leads to the conclusion that total phenolics (flavonoids, tannins) possess and contributed to high antioxidative potential. There was a negative correlation between tannin, flavonoid, total phenolic content and antioxidative capacity with whitefly count $(\mathrm{r}=-0.119, \mathrm{r}=-0.156, \mathrm{r}=-0.142$ and $\mathrm{r}=-0.181)$ respectively and similar negative association with leaf damage $(\mathrm{r}=-0.438, \mathrm{r}=-0.327, \mathrm{r}=-0.497$ and $\mathrm{r}=-0.667)$ respectively. The results illustrated that phenolics affect B. tabaci numbers and feeding as shown in CS1-144 where increase in total phenolics reduced whitefly count and leaf damage and vice versa in UG 130075 (Figure 1). According to Bennet and Wallsgrove (1994), phenolics act as enzyme inhibitors and feeding deterrents for insect herbivores while providing resistance against pathogens, through a possible reduction in plant nutrient content as reported by Kumar, Bohra, M. Pandey, and K. Pandey (2017).

The high regression values (Table 8 ) obtained for total phenolic content and antioxidative capacity with $\mathrm{R}^{2}=$ -0.117 and $R^{2}=0.228$ respectively, reaffirm that total phenolics and antioxidative capacity were associated more to leaf damage. Reason being in plants, phenolics can act as antioxidants as reported by Sakihama, Cohen, Grace, and Yamasaki (2002) through donating electrons to guaiacol-type peroxidases for the detoxification of $\mathrm{H}_{2} \mathrm{O}_{2}$ produced under stress conditions such as leaf damage. The results are in agreement with findings conducted on Adiantum caudatum leaves, where a high antioxidative capacity was recorded in aqueous extract and associated to high phenolic content (Ahmed et al., 2015). The relationship of antioxidative capacity to leaf damage, implied the metabolite use as an early complementary measure for plant resistance to B. tabaci (Kimmins et al., 2005).

In this study, maximum temperatures had high regression coefficient $\left(\mathrm{R}^{2}=0.124\right)$ in relation to leaf damage, which indicated increased B. tabaci activity (Table 3). The increase in temperature has been reported to increase activity and $B$. tabaci feeding due to a high insect energy level requirement inducing high metabolic rates and 
need for food (Colvin, 2012), as part of pest growth (Kerchev et al., 2012). Similar results were reported in tomato where there was an increased $B$. tabaci activity at high-temperature locations (Zeshan, Khan, Ali, \& Arshad, 2015). Temperatures ranged between $33.03{ }^{\circ} \mathrm{C}$ (maximum temperature) and $15.74{ }^{\circ} \mathrm{C}$ (minimum temperature). In agreement to Clissfold and Simpson (2015), overall insect consumption rates increase with temperatures between 20 and $30{ }^{\circ} \mathrm{C}$, reported to increase hemiptera insect metabolic demands by increasing exponentially with rising temperatures, and increase food intake (Lemoine et al., 2014).

\section{Conclusions}

There was high variability among cassava genotypes for leaf damage, flavonoid, tannin, phenolic content and antioxidative capacity indicating possible benefit to strategic selection of genotypes. Genotypes CS1-144, UG 120124, UG 120257 and UG 120291 had low leaf damage scores, increased tannin, flavonoid, total phenolic concentrations and antioxidative capacity and were relatively stable among the traits across all the environments tested. High total phenolic content and antioxidative capacity can be used as indicators of leaf damage in cassava genotypes. Total phenolic increase contributed more to antioxidative capacity, reduced whitefly count and leaf damage and could be useful to select for cassava resistance to $B$. tabaci pest.

\section{References}

Adjebeng-Danquah, J., Manu-aduening, J., Gracen, V. E., Asante, I. K., \& Offei, S. K. (2017). AMMI Stability Analysis and Estimation of Genetic Parameters for Growth and Yield Components in Cassava in the Forest and Guinea Savannah Ecologies of Ghana. International Journal of Agronomy, 2017, 1-10. https://doi.org/ $10.1155 / 2017 / 8075846$

Adriko, J., Sserubombwe, W. S., Adipala, E., Bua, A., Thresh, J. M., \& Edema, R. (2011). Response of improved cassava varieties in Uganda to cassava mosaic disease (CMD) and their inherent resistance mechanisms. African Journal of Agricultural Research, 6(3), 521-531. https://doi.org/10.5897/AJAR07.140

Ahmed, D., Khan, M., \& Saeed, R. (2015). Comparative Analysis of Phenolics, Flavonoids, and Antioxidant and Antibacterial Potential of Methanolic, Hexanic and Aqueous Extracts from Adiantum caudatum Leaves. Antioxidants, 4(2), 394-409. https://doi.org/10.3390/antiox4020394

Alicai, T., Ndunguru, J., Sseruwagi, P., Tairo, F., Okao-Okuja, G., Nanvubya, R., ... Boykin, L. M. (2016). Cassava brown streak virus has a rapidly evolving genome: Implications for virus speciation, variability, diagnosis and host resistance. Scientific Reports, 6(October), 1-14. https://doi.org/10.1038/srep36164

Anbuselvi, S., \& Balamurugan, T. (2014). Phytochemical and antinutrient constituents of cassava and sweet potato. World Journal of Pharmacy and Pharmaceutical Sciences, 3(3), 1440-1449. Retrieved from http://www.wjpps.com/admin/assets/article_issue/1396443500.pdf

Apak, R., Özyürek, M., Güçlü, K., \& Çapanołlu, E. (2016). Antioxidant Activity/Capacity Measurement. 2. Hydrogen Atom Transfer (HAT)-Based, Mixed-Mode (Electron Transfer (ET)/HAT), and Lipid Peroxidation Assays. Journal of Agricultural and Food Chemistry, 64(5), 1028-1045. https://doi.org/ 10.1021/acs.jafc.5b04743

Aruna, C., Bhagwat, V. R., Sharma, V., Hussain, T., Ghorade, R. B., Khandalkar, H. G., ... Seetharama, N. (2011). Genotype $\times$ environment interactions for shoot fly resistance in sorghum (Sorghum bicolor (L.) Moench): Response of recombinant inbred lines. Crop Protection, 30(6), 623-630. https://doi.org/10.1016/ j.cropro.2011.02.007

Ballhorn, D. J., Kautz, S., Jensen, M., Schmitt, I., Heil, M., \& Hegeman, A. D. (2011). Genetic and environmental interactions determine plant defences against herbivores. Journal of Ecology, 99(1), 313-326. https://doi.org/10.1111/j.1365-2745.2010.01747.x

Barah, P., \& Bones, A. M. (2017). Multidimensional approaches for studying plant defence against insects: From ecology to omics and synthetic biology. Journal of Experimental Botany, 66(2), 479-493. https://doi.org/ $10.1093 / \mathrm{j} x \mathrm{~b} / \mathrm{eru} 489$

Bellotti, A. C. (2002). Arthropod pests. In R. J. Hillocks, J. M. Thresh, \& A. C. Bellotti (Eds.), Cassava: Biology, production and utilization (p. 332). Cali, Colombia: CAB International. https://doi.org/10.1079/ 9780851995243.0209

Bellotti, A. C., \& Arias, B. (2001). Host plant resistance to whiteflies with emphasis on cassava as a case study. Crop Protection, 20, 813-823. https://doi.org/10.1016/S0261-2194(01)00113-2

Bennett, R. N., \& Wallsgrove, R. M. (1994). Secondary metabolites in plant defence mechanisms. New 
Phytologist, 127(4), 617-633. https://doi.org/10.1111/j.1469-8137.1994.tb02968.x

Bohorquez, A., Tohme, J., Parsa, S., \& López-Lavalle, L. A. B. (2001). Phenotyping cassava (Manihot esculenta) resistance to whitefly (Aleurotrachelus socialis). Colombia: CIAT.

Burns, A. E., Gleadow, R. M., Zacarias, A. M., Cuambe, C. E., Miller, R. E., \& Cavagnaro, T. R. (2012). Variations in the chemical composition of cassava (Manihot esculenta Crantz) leaves and roots as affected by genotypic and environmental variation. Journal of Agricultural and Food Chemistry, 60(19), 4946-4956. https://doi.org/10.1021/jf2047288

Caffrey, P., Finan, T., Trzaska, S., Miller, D., Laker-Ojok, R., \& Huston, S. (2013). Uganda climate change vulnerability assessment report.

Carriero, G., Brunetti, C., Fares, S., Hayes, F., Hoshika, Y., Mills, G., ... Paoletti, E. (2016). BVOC responses to realistic nitrogen fertilization and ozone exposure in silver birch. Environmental Pollution, 213(June), 988-995. https://doi.org/10.1016/j.envpol.2015.12.047

CIAT. (2005). In F. J. M. Pamela \& K. Anderson (Eds.), Whitefly and whitefly borne viruses in the tropics: Building a knowledge base for global action (Publication No. 341). Colombia: CIAT.

CIAT. (2011). In R. H. Howeler (Ed.), A Reference Manual based on the Asian Regional Cassava Training Course, Held in Thailand. Thailand: CIAT.

Colvin, J. (2012). Insects, Plants and Viruses: Dynamic Interactions in a Changing World (1st ed.). Greenwich: National association of paper merchants.

FAO. (2017). FAOSTAT. Food and Agriculture Organization of the United Nations. Retrieved from http://www.fao.org/home/en

Fürstenberg-hägg, J., Zagrobelny, M., \& Bak, S. (2013). Plant Defense against Insect Herbivores. International of Molecular Sciences, 14, 10242-10297. https://doi.org/10.3390/ijms140510242

Hasanuzzaman, M., Nahar, K., \& Fujita, M. (2009). Extreme Temperature Responses, Oxidative Stress and Antioxidant Defense in Plants. Jnci Journal of the National Cancer Institute, 65(1), 81-93. https://doi.org/10.5772/54833

Hongyu, K., García-Peña, M., Araújo, L. B. de, \& Santos Dias, C. T. dos. (2014). Statistical analysis of yield trials by AMMI analysis of genotype $\times$ environment interaction. Biometrical Letters, 51(2), 89-102. https://doi.org/10.2478/bile-2014-0007

HoRTUS Technical. (2017). Sap Testing Plant Sampling, 2017.

Huber, A. E., \& Bauerle, T. L. (2016). Long-distance plant signaling pathways in response to multiple stressors: The gap in knowledge. Journal of Experimental Botany, 67(7), 2063-2079. https://oi.org/10.1093/ jxb/erw099

Huber, M., Epping, J., Schulze Gronover, C., Fricke, J., Aziz, Z., Brillatz, T., ... Erb, M. (2016). A Latex Metabolite Benefits Plant Fitness under Root Herbivore Attack. PLoS Biology, 14(1), 1-27. https://doi.org/ 10.1371/journal.pbio.1002332

Jamieson, M. A., Burkle, L. A., Manson, J. S., Runyon, J. B., Trowbridge, A. M., \& Zientek, J. (2017). Global change effects on plant-insect interactions: The role of phytochemistry. Current Opinion in Insect Science, 23, 70-80. https://doi.org/10.1016/j.cois.2017.07.009

Kant, M. R., Jonckheere, W., Knegt, B., Lemos, F., Liu, J., Schimmel, B. C. J., ... Alba, J. M. (2015). Mechanisms and ecological consequences of plant defence induction and suppression in herbivore communities. Annals of Botany, 115(7), 1015-1051. https://doi.org/10.1093/aob/mcv054

Kayondo, S. I., Del Carpio, D. P., Lozano, R., Ozimati, A., Wolfe, M. D., Baguma, Y., ... Jannink, J.-L. (2017). Genome-wide association mapping and genomic prediction unravels CBSD resistance in a Manihot esculenta breeding population. bioRxiv, January, 158543. https://doi.org/10.1038/s41598-018-19696-1

Kempema, L. A., Cui, X., Holzer, F. M., \& Walling, L. L. (2007). Arabidopsis Transcriptome Changes in Response to Phloem-Feeding Silverleaf Whitefly Nymphs. Similarities and Distinctions in Responses to Aphids. Plant Physiology, 143(February), 849-865. https://doi.org/10.1104/pp.106.090662

Kerchev, P. I., Fenton, B., Foyer, C. H., \& Hancock, R. D. (2012). Plant responses to insect herbivory: Interactions between photosynthesis, reactive oxygen species and hormonal signalling pathways. Plant, Cell and Environment, 35, 441-453. https://doi.org/10.1111/j.1365-3040.2011.02399.x 
Kimmins, F., Chancellor, T., Gibson, R., Colvin, J., Adolph, B., Legg, J., ... Morales, F. (2005). Output 4: Global IPM networks (Integrated Whitefly Management Technology) and knowledge systems developed.

Kivimäenpää, M., Ghimire, R. P., Sutinen, S., Halkio, E., Kasurinen, A., \& Holopainen, T. H. J. (2016). Increases in volatile organic compound emissions of Scots Pine in response to elevated ozone and warming are modified by herbivory and soil nitrogen availability. European Journal of Forest Research, 135(2), 1-18. https://doi.org/10.1007/s10342-016-0939-X

Kloth, K. J., Thoen, M. P. M., Bouwmeester, H. J., Jongsma, M. A., \& Dicke, M. (2012). Association mapping of plant resistance to insects. Trends in Plant Science, 17(5), 311-319. https://doi.org/10.1016/j.tplants. 2012.01.002

Kumar, R., Bohra, A., Pandey, A. K., \& Pandey, M. K. (2017). Metabolomics for Plant Improvement: Status and Prospects. Front. Plant Sci., 8(August), 1-27. https://doi.org/10.3389/fpls.2017.01302

Kumar, T., \& Jain, V. (2015). Appraisal of Total Phenol, Flavonoid Contents, and Antioxidant Potential of Folkloric Lannea coromandelica Using in vitro and in vivo Assays. Scientifica, 2015, Article ID 203679. https://doi.org/10.1155/2015/203679

Lemoine, N. P., Burkepile, D. E., \& Parker, J. D. (2014). Variable effects of temperature on insect herbivory. PeerJ, 2, e376. https://doi.org/10.7717/peerj.376

Linacre, E., \& Geerts, B. (1997). Climates and weather explained. Routledge. https://doi.org/10.4324/ 9780203291030

Maksimović, J. J. D., \& Živanović, B. D. (2012). Quantification of the Antioxidant Activity in Salt Stres. In S. Shabala \& T. Cuin (Eds.), Plant Salt Tolerance. Methods in Molecular Biology (Methods and Protocols) (1st ed., Vol. 913, pp. 237-250). Belgrade, Serbia: Humana Press, Totowa, NJ. https://doi.org/10.1007/ 978-1-61779-986-0_16

Matilla, A. J. (2012). Environmental Adaptations and Stress Tolerance of Plants in the Era of Climate Change. Biomedical and Life Sciences (pp. 361-380). Springer, New York, NY. https://doi.org/10.1007/ 978-1-4614-0815-4_16

Moore, B. D., Andrew, R. L., Külheim, C., \& Foley, W. J. (2014). Explaining intraspecific diversity in plant secondary metabolites in an ecological context. The New Phytologist, 201(3), 733-50. https://doi.org/ $10.1111 /$ nph. 12526

Mtunguja, M. K., Laswai, H. S., Kanju, E., Ndunguru, J., \& Muzanila, Y. C. (2016). Effect of genotype and genotype by environment interaction on total cyanide content, fresh root, and starch yield in farmer-preferred cassava landraces in Tanzania. Food Science \& Nutrition, 4(6), 791-801. https://doi.org/ $10.1002 /$ fsn 3.345

Ncube, B., Finnie, J. F., \& Van Staden, J. (2012). Quality from the field: The impact of environmental factors as quality determinants in medicinal plants. South African Journal of Botany, 82, 11-20. https://doi.org/ 10.1016/j.sajb.2012.05.009

Ntawuruhunga, P., \& Dixon, A. G. O. (2010). Quantitative variation and interrelationship between factors influencing cassava yield. Journal of Applied Biosciences, 26, 1594-1602. Retrieved from http://m.elewa. org/JABS/2010/26/1.pdf

Nuwamanya, E., Rubaihayo, P. R., Mukasa, S., Kyamanywa, S., Hawumba, J. F., \& Baguma, Y. (2014). Biochemical and secondary metabolites changes under moisture and temperature stress in cassava (Manihot esculenta Crantz). African Journal of Biotechnology, 13(31), 3173-3186. https://doi.org/10.5897/AJB2014. 13663

Nweke, F. (2009). Controlling Cassava Mosaic Virus and Cassava Mealybud in Sub-Saharan Africa. IFPRI Discussion Paper 00912. Washington, DC: International Food Policy Research Institute.

Okoth, S., Rose, L. J., Sila, H., \& Viljoen, A. (2017). Assessing Genotype-By-Environment Interactions in Aspergillus Ear Rot and Pre-Harvest Aflatoxin Accumulation in Maize Inbred Lines. Agronomy, 7(4), 86. https://doi.org/10.3390/agronomy7040086

Pandey, P., Irulappan, V., Bagavathiannan, M. V., \& Senthil-Kumar, M. (2017). Impact of Combined Abiotic and Biotic Stresses on Plant Growth and Avenues for Crop Improvement by Exploiting Physio-morphological Traits. Frontiers in Plant Science, 8(April), 1-15. https://doi.org/10.3389/fpls.2017.00537

Paparu, P., Acur, A., Kato, F., Acam, C., Nakibuule, J., Musoke, S., ... Mukankusi, C. (2017). Prevalence and 
Incidence of Four Common Bean Root Rots in Uganda. Experimental Agriculture, 2017, 1-13. https://doi.org/10.1017/S0014479717000461

Pisoschi, A. M., Pop, A., Cimpeanu, C., \& Predoi, G. (2016). Antioxidant capacity determination in plants and plant-derived products: A review. Oxidative Medicine and Cellular Longevity, 2016, Article ID 9130976. https://doi.org/10.1155/2016/9130976

Purchase, J. L., Hatting, H., \& van Deventer, C. S. (2000). Genotype $\times$ environment interaction of winter wheat (Triticum aestivum L.) in South Africa: II. Stability analysis of yield performance. South African Journal of Plant and Soil, 17(3), 101-107. https://doi.org/10.1080/02571862.2000.10634878

Ramegowda, V., \& Senthil-Kumar, M. (2015). The interactive effects of simultaneous biotic and abiotic stresses on plants: Mechanistic understanding from drought and pathogen combination. Journal of Plant Physiology, 176, 47-54. https://doi.org/10.1016/j.jplph.2014.11.008

Rejeb, I., Pastor, V., \& Mauch-Mani, B. (2014). Plant Responses to Simultaneous Biotic and Abiotic Stress: Molecular Mechanisms. Plants, 3(4), 458-475. https://doi.org/10.3390/plants3040458

Sakihama, Y., Cohen, M. F., Grace, S. C., \& Yamasaki, H. (2002). Plant phenolic antioxidant and prooxidant activities: Phenolics-induced oxidative damage mediated by metals in plants. Toxicology, 177(1), 67-80. https://doi.org/10.1016/S0300-483X (02)00196-8

Shamloo, M., Babawale, E. A., Furtado, A., Henry, R. J., Eck, P. K., \& Jones, P. J. H. (2017). Effects of genotype and temperature on accumulation of plant secondary metabolites in Canadian and Australian wheat grown under controlled environments. Scientific Reports, 7(1), 9133. https://doi.org/10.1038/s41598-017-09681-5

Sharma, P., Jha, A. B., Dubey, R. S., \& Pessarakli, M. (2012). Reactive Oxygen Species, Oxidative Damage, and Antioxidative Defense Mechanism in Plants under Stressful Conditions. Journal of Botany, 2012, Article ID 217037. https://doi.org/10.1155/2012/217037

Singh, D. K., Srivastava, B., \& Sahu, A. (2004). Spectrophotometric determination of Rauwolfia alkaloids: Estimation of reserpine in pharmaceuticals. Analytical Sciences: The International Journal of the Japan Society for Analytical Chemistry, 20(3), 571-573. https://doi.org/10.2116/analsci.20.571

Stevens, M. T., Waller, D. M., \& Lindroth, R. (2007). Resistance and tolerance in Populus tremulo ides: Genetic variation, costs, and environmental dependency. Evolutionary Ecology, 21, 829-847. https://doi.org/ $10.1007 / \mathrm{s} 10682-006-9154-4$

Sulistyo, A., \& Inayati, A. (2016). Mechanisms of antixenosis, antibiosis, and tolerance of fourteen soybean genotypes in response to whiteflies (Bemisia tabaci). Biodiversitas, 17(2), 447-453. https://doi.org/ 10.13057/biodiv/d170207

Tukamuhabwa, P., Oloka, H. K., Sengooba, T., \& Kabayi, P. (2012). Yield stability of rust-resistant soybean lines at four mid-altitude tropical locations. Euphytica, 183(1), 1-10. https://doi.org/10.1007/s10681-011-0404-3

Tylianakis, J. M., Didham, R. K., Bascompte, J., \& Wardle, D. A. (2008). Global change and species interactions in terrestrial ecosystems. Ecology Letters, 11(12), 1351-1363. https://doi.org/10.1111/j.1461-0248.2008. 01250.x

van Bel, A. J. E. (2006). Sieve pore plugging mechanisms. Cell-Cell Channels (p. 46957). Springer, New York, NY. https://doi.org/10.1007/978-0-387-46957-7_7

VanDoorn, A., \& Vos, M. de. (2013). Resistance to sap-sucking insects in modern-day agriculture. Frontiers in Plant Science, 4(June), 1-8. https://doi.org/10.3389/fpls.2013.00222

War, A. R., Paulraj, M. G., Ahmad, T., Buhroo, A. A., Hussain, B., Ignacimuthu, S., \& Sharma, H. C. (2012). Mechanisms of plant defense against insect herbivores. Plant Signaling \& Behavior, 7(10), 1306-1320. https://doi.org/10.4161/psb.21663

Zeshan, M. A., Khan, M. A., Ali, S., \& Arshad, M. (2015). Correlation of Conducive Environmental Conditions for the Development of Whitefly, Bemisia tabaci Population in Different Tomato Genotypes. Pakistan Journal of Zoology, 47(6), 1511-1515.

Zhang, L., Ye, G., Lin, Y., Zhou, H., \& Zeng, Q. (2009). Seasonal changes in tannin and nitrogen contents of Casuarina equisetifolia branchlets. Journal of Zhejiang University, Science B, 10(2), 103-111. https://doi.org/10.1631/jzus.B0820217 
Zobayed, S. M. A., Afreen, F., Goto, E., \& Kozai, T. (2006). Plant-environment interactions: Accumulation of hypericin in dark glands of Hypericum perforatum. Annals of Botany, 98(4), 793-804. https://doi.org/ $10.1093 / \mathrm{aob} / \mathrm{mcl} 169$

\section{Copyrights}

Copyright for this article is retained by the author (s), with first publication rights granted to the journal.

This is an open-access article distributed under the terms and conditions of the Creative Commons Attribution license (http://creativecommons.org/licenses/by/4.0/). 